Keys, A., Fidanza, F., Scardi, V. \& Bergami, G. (1952). Lancet, 263, 209.

Keys, A., Fidanza, F., Scardi, V., Bergami, G. \& Keys, M. H. (1954). Arch. intern. Med. (In the Press.) Keys, A., Mickelsen, O., Miller, E. v. O. \& Chapman, C. B. (I950). Science, I12, 79.

Keys, A., Mickelsen, O., Miller, E. v. O., Hayes, E. R. \& Todd, R. L. (1950). F. clin. Invest. 29, 1347.

Keys, A., Vivanco, F., Rodriguez-Miñon, J. L., Keys, M. H. \& Castro-Mendozo, H. (r954). Metabolism. (In the Press.)

Kornerup, V. (1950). Arch. intern. Med. 85, 398.

Messinger, W. J., Porosowska, Y. \& Steele, J. M. (1950). Arch. intern. Med. 86, 189.

Moses, C. (1952). Amer. F. med. Sci. 224, 212.

Ministry of Food: National Food Survey Committee (1951). The Urban Working-class Household Diet 1940 to 1949. London: H.M. Stationery Office.

Oliver, M. F. \& Boyd, G. S. (1953). Brit. Heart F. 15, 387.

Peeler, A. L., Hepler, O. E., Kinney, V. M. Cisler, L. E. \& Jung, F. T. (1950-1). F. appl. Physiol. 3, 197.

Pomeranze, J., Green, M. B. \& Goldbloom, A. (1952). Bull. N.Y. Acad. Med. 28, 6II.

Schwartz, W. B. \& Merlis, J. K. (1948). F. clin. Invest. 27, 406.

Tanner, J. M. (1951). F. Physiol. 115, 371.

U.S. Department of Agriculture: Bureau of Human Nutrition and Home Economics (1949). Food Consumption Surveys, Preliminary Report, no. 9.

Wilkinson, C. F., Jr., Blecha, E. \& Reimer, A. (1950). Arch. intern. Med. 85, 389.

\title{
The Food Intake and Energy Expenditure of Gadets in Training
}

\author{
By ELSIE M. WIDDOWSON, O. G. EDHOLM ANd R. A. McCANCE \\ Medical Research Council Department of Experimental Medicine, \\ University of Cambridge, and Division of Human Physiology, \\ National Institute for Medical Research, London, N.W.3
}

(Received 4 November 1953)

If groups of adults are maintaining a steady average weight, it may be assumed that their calorie intake is meeting their requirements. Standard growth curves have been established for children and if a group of them is growing satisfactorily their nutritional requirements are probably being covered by the food provided for them. It is not, however, so easy to be sure of this at an age when growth may or may not be complete and when a gain in weight might be desirable owing to muscular development even if growth in height has ceased.

This was the problem facing those responsible for the health of a large number of young men aged $18 \frac{1}{2}-20$ years at one of the training establishments for the armed forces. The authors of this paper were consulted: they were told of the quantities and nature of the food provided by the authorities, and also the other sources from which the trainees were in the habit of obtaining additional food. On paper the 'issued' rations had a value of $3_{819} \mathrm{Cal} / \mathrm{man} / \mathrm{day}$. This seemed generous enough but it was repeatedly represented to the authors that the trainees led a most strenuous life, and that they did not appear to be gaining weight as it was thought they should. Since little was known about the energy expenditure and the food requirements of young men of this age the matter seemed one for investigation. 


\section{Feeding arrangements at the training establishment}

In order to appreciate the significance of the results of this inquiry it is necessary to know something about the feeding arrangements at the establishment under consideration. When this investigation was made (in May 1952) breakfast was served in the dining room at $7.3^{\circ} \mathrm{a} . \mathrm{m}$. The cadets had to attend, and there was no method of supplementing this meal. It consisted of porridge or cornflakes and a cooked dish which always had fried bread served with it. Each cadet was supplied with some marmalade and $\frac{1}{2} \mathrm{oz}$. ( $\mathrm{I} 4 \mathrm{~g}$ ) of butter on his plate and there was plenty of bread on the table. Between I0.I 5 and ro.45 a.m. the canteens served cakes, buns, sausages, milk and various soft drinks, for which the cadets paid out of their own money. A twocourse lunch began at $\mathbf{2} 2.45$ p.m. which nearly all the cadets attended although it was not compulsory. The canteens were open before, during and after this meal. 'Tea' was provided at 4 p.m. which was attended by about half the cadets. It consisted of bread ad lib., jam which was served in dishes on the table, and a 'portion' of margarine, with a plain cake or bun which was placed on each man's plate. The canteen was open as an alternative. Formal dinner was served at 8 p.m. on 4 days during the week. This consisted of soup, a meat course and some kind of sweet which varied from icecream to steamed pudding. Both at lunch and dinner there was bread on the table, and the cadets helped themselves to potatoes and vegetables. The former were served roasted, boiled, mashed or fried. On the other 3 days of the week, supper was served at $7.30 \mathrm{p} . \mathrm{m}$. This also consisted of soup, a meat course and a sweet, but the vegetables were put on the plates. On these 3 days the canteens were open in the evening, and the cadets were also allowed to sign off and to go outside for their evening meal. The food for the dining hall was well cooked and well served but there were no second helpings for the large eaters and no alternative dishes for those who did not fancy what was provided.

\section{General}

\section{EXPERIMENTAL}

Our study lasted for I week and was made by two groups of investigators who worked independently. One devoted itself to an estimate of the average daily food intake of seventy-seven cadets and the other to the energy expenditure of the same men. The results obtained were not compared until the whole investigation was completed. The average age of the cadets was I9 years 9 months, their average weight $68 \mathrm{~kg}$, height $178 \mathrm{~cm}$ and surface area 1.83 sq.m. The seventy-seven cadets formed one unit in a much larger organization. Each unit was similarly constituted so that the seventyseven investigated may be taken to have been representative of the whole establishment.

\section{Measurement of the food intake}

All the food provided in the dining hall for the seventy-seven cadets was weighed at each meal during $x$ complete week. The unserved portions of the food were also weighed, and the plate waste. The composition of cooked dishes was arrived at by weighing all the raw ingredients and the final cooked dish as served to the cadets. Each cadet kept a record each day of all food and drink he bought at the canteen and also of any 
food obtained from sources outside the establishment. The weights of the different varieties of cakes and other extras and the volumes of the various drinks served in the canteens were measured and their composition ascertained from a knowledge of their ingredients.

From these records the calorie, protein, fat, carbohydrate, alcohol, calcium and iron intakes of the cadets were calculated from food tables (McCance \& Widdowson, 1946), and the proportion of each which the cadets obtained from the food they ate in the dining hall, the canteens and outside. The amounts of the various dietary essentials obtained from the food actually eaten in the dining hall were compared with the amounts the cadets could have obtained had they eaten the whole of the rations issued or purchased for the meals in the dining hall, and the nutritive value of the uneaten rations was compared with the nutritive value of the food and drink bought at the canteen or eaten outside the establishment. The figures given in all the tables are averages for all the seventy-seven cadets.

\section{Estimate of the energy expenditure}

The cadets were issued with a paper every day on which they recorded their activities. The completed forms were collected, and the new ones distributed, at breakfast. The entries were checked, and any discrepancies noted were discussed with the individual cadets. The details provided in the daily forms varied considerably but were in all instances adequate: none of the forms were lost or spoiled. The cadets adhered to precise time tables, so it was relatively easy to confirm the entries made. The figures given for the time spent in various activities may therefore be considered reasonably accurate.

All the major activities in which the cadets were engaged were carefully observed and timed. These activities included drill, fitness training in the gymnasium, tactical exercises, shooting, driving and maintenance of army vehicles, games and sports. Several measurements of oxygen consumption were made, by analysis of expired air collected in Douglas bags, during various phases of drill and fitness training.

The daily forms were subsequently analysed in detail, and every minute of the day accounted for, under the following headings: sleep, measured as time spent in bed; sitting, including meals, instruction periods, attendance at hospital and hairdresser; standing, including periods of standing in practical classes, but not standing during military training or during games; washing and dressing, including time spent in changing clothes during the day; cleaning uniform, including ironing, polishing and leather work; drill, including roll calls and all parades; cycling and walking (distances given by cadets were checked by measurement on a large-scale map); light activities, including a variety of events that could not be classified under any other heading; games and sports, including the whole time spent at a particular game or sport, e.g. in cricket there would frequently be time spent sitting in the pavilion, but this would come under the heading of 'cricket'.

When the daily events had been divided under these various headings, the figures for the times were transferred to a second form, of which there was one for each cadet, separated into columns for the 7 days of observation. The calorie expenditure for each 
i 5 O Elsie M. Widdowson, O. G. Edholm and R. A. McCance 1954 activity was computed as so many $\mathrm{Cal} . / \mathrm{m}^{2} / \mathrm{min}$. The values used for fitness training and drill were based on the direct determinations of oxygen consumption made for the purpose; for all other occupations the figures given by other workers have been taken (Orr \& Leitch, 1937-8). Where relevant, energy expenditure determinations by

Table I. Values used for energy expenditure

\begin{tabular}{|c|c|c|c|}
\hline Activity & Cal. $/ \mathrm{m}^{2} / \mathrm{min}$ & Activity & Cal. $/ \mathrm{m}^{2} / \mathrm{min}$ \\
\hline Sleeping & 0.66 & Music & \\
\hline Sitting & $1 \cdot 075$ & Choir practice & $I \cdot 4$ \\
\hline Standing & $1 \cdot 33$ & Playing: & \\
\hline Dressing and washing & I.94 & Double bass & $1 \cdot 5$ \\
\hline Cleaning uniforms & $I \cdot 93$ & Bagpipes & $1 \cdot 5$ \\
\hline Light activities & $1 \cdot 82$ & Accordion & $I \cdot 25$ \\
\hline Ironing & $1 \cdot 43$ & Violin & $1 \cdot 4$ \\
\hline Walking & $4^{\circ} 0$ & Drum & $I \cdot 3$ \\
\hline Cycling & $4 \cdot 8$ & Piano & $2 \cdot 0$ \\
\hline Drill & $2 \cdot 5$ & Saxophone & $1 \cdot 4$ \\
\hline Fitness training & $5 \cdot 0$ & & \\
\hline Tactical exercises & $2 \cdot 0$ & & \\
\hline Weapon training & $1 \cdot 8$ & & \\
\hline Range duties & $1 \cdot 5$ & & \\
\hline Shooting & $1 \cdot 3$ & & \\
\hline Driving & $1 \cdot 2$ & & \\
\hline Motor cycling & $1 \cdot 3$ & & \\
\hline Games and recreation: & & Miscellaneous: & \\
\hline Athletics & $4 \cdot 5$ & Dancing & $2 \cdot 0$ \\
\hline Running & $5^{\circ} \cdot$ & Carrying shrubs & $3 \cdot 5$ \\
\hline Badminton & $3 \cdot 5$ & Gardening & $3 \cdot 5$ \\
\hline Billiards & $1 \cdot 5$ & Lifting sacks & $4^{\circ} \cdot 0$ \\
\hline Basket ball & 5.0 & Moving furniture & 4.0 \\
\hline Boxing (in ring) & $8 \cdot 0$ & Pushing motor cycle & 4.5 \\
\hline Boxing (sparring) & $5^{\circ} 0$ & Hospital treatment & $1 \cdot 2$ \\
\hline Cricket & $1 \cdot 5$ & Physiotherapy & $x \cdot 3$ \\
\hline Climbing & 5.0 & & \\
\hline Coxing & $1 \cdot 3$ & & \\
\hline Darts & $1 \cdot 4$ & & \\
\hline Golf & $2 \cdot 9$ & & \\
\hline Judo & $8 \cdot 0$ & & \\
\hline Ragging & $6 \cdot 0$ & & \\
\hline Riding & $1 \cdot 5$ & & \\
\hline Rowing & $4^{\circ} 0$ & & \\
\hline Sailing & $x \cdot 3$ & & \\
\hline Squash & $5^{\circ} 0^{\circ}$ & & \\
\hline Snooker & $1 \cdot 5$ & & \\
\hline Swimming & $4^{\circ} 0$ & & \\
\hline Table tennis & $2 \cdot 0$ & & \\
\hline Tennis & $3 \cdot 5$ & & \\
\hline
\end{tabular}

Passmore, Thomson \& Warnock (1952) have been used, as these were obtained on young adult male students. The activities concerned and the values for energy expenditure used are shown in Table r. These values were multiplied by the surface area of the individual cadet, and by the time, in minutes, spent in the particular activity. The energy expenditure during sleep has been taken as equal to the calculated basal metabolic rate, i.e. $40 \mathrm{Cal} . / \mathrm{m}^{2} / \mathrm{h}$ or $0.66 \mathrm{Cal} . / \mathrm{m}^{2} / \mathrm{min}$. 


\section{Food intake}

RESULTS

Table 2 gives a summary of the average intake of calories, protein, fat, carbohydrate, alcohol, calcium and iron, and the sources from which these nutrients were derived. The average daily calorie intake of all the cadets over the whole week was 3705 Cal. Of these, 2527 or $68 \%$ of the total came from food provided and eaten in the dining hall, $20 \%$ from food and drink bought by the cadets in the canteen and $12 \%$ from food obtained 'outside'. Although the calories obtained from outside sources could not be assessed as accurately as calories derived from the food actually weighed, the figures were probably fairly near the truth.

The cadets by no means ate the whole of the rations provided for them. Table 3 shows a comparison of the amounts of the various dietary ingredients that the cadets

Table 2. Composition of the average diet of the cadets and the sources from which the various nutrients were derived

$\begin{array}{lcccc}\text { Component } & \begin{array}{c}\text { Average } \\ \text { intake/day }\end{array} & \text { Mess } & \text { Canteen } & \text { Outside } \\ \text { Calories (Cal.) } & 3705 & 68 & 20 & 12 \\ \text { Protein (g) } & 104 & 74 & 16 & 10 \\ \text { Fat (g) } & 139 & 67 & 20 & 13 \\ \text { Carbohydrate (g) } & 509 & 70 & 20 & 10 \\ \text { Alcohol (g) } & 11 & 0 & 40 & 60 \\ \text { Calcium (g) } & 1 \cdot 28 & 70 & 21 & 9 \\ \text { Iron (mg) } & 23 \cdot 7 & 74 & 15 & 11\end{array}$

Table 3. Comparison of the composition of the food eaten and uneaten by the cadets

\begin{tabular}{|c|c|c|c|c|}
\hline \multirow[b]{2}{*}{ Component } & \multicolumn{3}{|c|}{ Total in mess } & \multirow{2}{*}{$\begin{array}{l}\text { Total eaten in } \\
\text { canteen and } \\
\text { outside }\end{array}$} \\
\hline & Provided & Eaten & Uneaten & \\
\hline Calories (Cal.) & 3714 & 2527 & I 187 & I 178 \\
\hline Protein (g) & 117 & 77 & 40 & 27 \\
\hline Fat (g) & I 18 & 93 & 25 & 46 \\
\hline Carbohydrate (g) & 564 & $35^{8}$ & 206 & I 51 \\
\hline Alcohol (g) & - & - & - & I I \\
\hline Calcium (g) & $I \cdot 35$ & 0.90 & 0.45 & $0.3^{8}$ \\
\hline Iron $(\mathrm{mg})$ & $25 \cdot 1$ & 17.7 & $7 \cdot 4$ & 6.0 \\
\hline
\end{tabular}

could have obtained from the food provided for them and the amounts in the food they actually ate. Over the week they ate only two-thirds of the food measured in terms of calories issued for them. By far the biggest source of wastage was the bread. The bread ration was $15 \mathrm{oz}$. $(426 \mathrm{~g}) / \mathrm{cadet} / \mathrm{day}$. The bread eaten, including fried bread and all bread used for cooking, amounted only to $6.4 \mathrm{oz}$. (182 g)/cadet/day. Of the 547 Cal. from foods other than bread not eaten by the cadets, 338 were never served and 209 came from plate waste. This loss was $7 \cdot 7 \%$ of the calories in the food served out to the cadets in the dining hall and $5.7 \%$ of the calories in the food provided for them by the authorities. These figures are higher than most of those given for the five army messes investigated by Arneil \& Badham (1948-9). Their magnitude was apparently due to the unpopularity of certain foods for which there was no alternative. 
I52 Elsie M. Widdowson, O. G. Edholm and R. A. McCance 1954

Table 3 also shows a comparison of the composition of the uneaten rations with the composition of the food which the cadets bought at the canteen and in restaurants outside. The food they bought provided them with almost the same number of calories as the food they refused so that their calorie intake was in fact the same as the calorie value of the food issued for them.

\section{Energy expenditure}

The average calorie expenditure of the seventy-seven cadets over the whole week was estimated to be $3420 \mathrm{Cal}$. a day. Although the average expenditure differed only slightly from day to day there was considerable variation in any one cadet from day to day, amounting to an average difference of $775 \mathrm{Cal}$. between the highest and lowest daily expenditure.

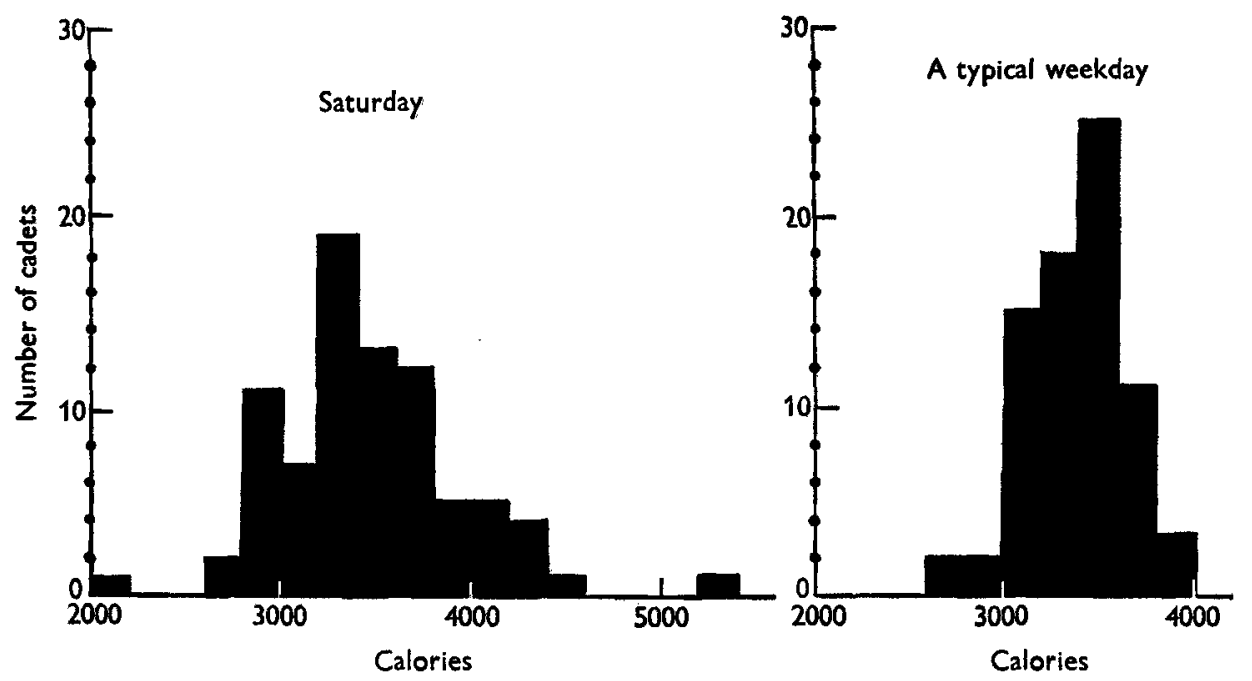

Fig. I. Distribution of calorie expenditure of the cadets.

The spread of the variation differed considerably as may be seen by comparing the distribution of the individual expenditures for a typical weekday with Saturday or Sunday (Fig. I). Some cadets were much more energetic at the week-end. Others had their lowest energy expenditure of the whole week during Saturday and Sunday. This was made possible by the greater freedom at the week-end. The average time spent on the various occupations is shown in Fig. 2. For ease of presentation, dressing and cleaning of uniforms were grouped together, military training included drill, weapon training and shooting, and walking and cycling were also put into one group. The variation between cadets was very slight for certain activities. The time spent in bed, for example, was almost constant, but the time spent on games and sports varied greatly and ranged from $\frac{1}{2} \mathrm{~h}$ in the whole week up to $\mathrm{I}_{5} \mathrm{~h}$. The proportion of the total energy expended on the different activities is also shown in Fig. 2. 


\section{DISCUSSION}

The results obtained in this study went some way towards solving the problems for which it had been undertaken. They did this partly by removing misconceptions. The cadets were not leading lives of intense activity. They spent $9 \frac{1}{4} \mathrm{~h}$ a day sitting, some of it at lectures, and $8 \frac{1}{2}$ in bed. Dressing, cleaning uniforms and getting about the grounds accounted for $28 \%$ of their total energy expenditure and were really their major physical activities. Drill and parades, which were a conspicuous feature of the training, were relatively unimportant, and so was sport, although it meant a great deal more to some men than to others. Their energy expenditure may have been rated a little too low in the light of their food intakes, but the latter at $3705 \mathrm{Cal} /$ /cadet/day
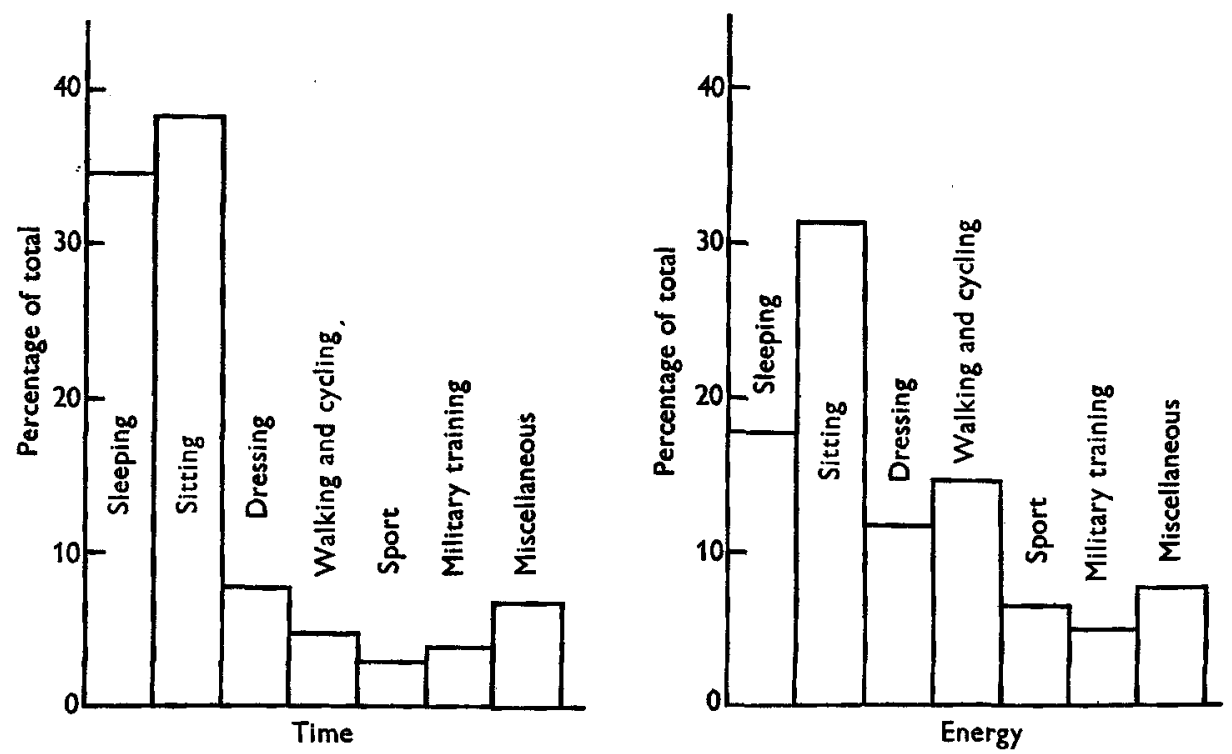

Fig. 2. Percentage of their time and energy which the cadets devoted to various occupations.

cannot be considered to compete with the figures given for American university football players (5600 Cal./day) (Edwards, Thorndike \& Dill, 1935) or for Olympic athletes ( $7300 \mathrm{Cal} /$ day) (Schenk, 1936 ) and must be reckoned to fall within the range required for moderate industrial work (Orr \& Leitch, 1937-8). The dietary requirement for hard work has been estimated by the (U.S.A.) National Research Council (1948) to be $4500 \mathrm{Cal} /$ day. It is possible that during some other week or at another time of year the results would have been rather different but the conclusions would probably have been the same.

The food provided by the authorities would have supplied $3714 \mathrm{Cal} /$ cadet/day. Had the cadets had no other source of calories they might have been short, for some wastage in preparation and serving is inevitable. The cadets only ate $68 \%$ of this food, however, and refused i 87 Cal./day of the available calories. They then bought food and drink equivalent to almost the same number of calories (x $78 \mathrm{Cal}$.). Table 3 shows that this meant a net loss of protein, carbohydrate, calcium and iron and a gain 
of fat and alcohol. This finding is a reflexion of the fact that, broadly speaking, the men refused the bread and bought cakes instead. In so far as protein, calcium and iron are nutritional substances more highly desirable than fat and alcohol, the diet the cadets ate was slightly inferior nutritionally to the one they might have eaten had they taken up the whole of their rations. These differences are small, however, and a more important question seems to be why the cadets preferred to leave so much of the food provided and to buy other food at the canteens. The answer to this would seem to be that the canteens provided food that the cadets liked and a service and social background that were lacking in the dining room. The meals in the dining room were eaten in an atmosphere of noise and rush. Lunch, for example, began at 12.45 ; by I p.m. most of the cadets had finished and had left the dining hall. This rush was not due to the fact that the cadets had no more time for their meal, because many of them left the dining hall only to move into the canteen where they were able to relax at small tables, smoke, drink coffee and eat cakes of their own choosing which they purchased at the counter. The service in the dining hall seemed to be a part of their regimented lives, whereas the canteen was an escape. It is probably true to say that the canteens would have been extensively patronized however good or plentiful the meals provided in the dining hall. They acted as 'buffers' in that they provided a big eater with the additional food he might require, and the 'particular' with the alternative food he might prefer. They also provided the means by which a cadet might obtain a meal if, in the pursuit of some duty or pleasure, he had had to miss the official one.

Those who live in an institution almost always complain about the food, and no system that does not offer alternatives will ever give mental satisfaction. The results of the present investigation suggest that a choice of commonplace foods, paid for at the counter and eaten at small tables, gives far more pleasure than more ambitious food eaten at long tables in a large dining hall. They also made it quite clear that the cadets have at their disposal more food than they choose to eat. If they do not gain weight a shortage of food cannot be held to be responsible.

\section{SUMMARY}

I. The energy expenditure of seventy-seven cadets in a training establishment has been estimated and found to average $3420 \mathrm{Cal}$./day. This is equivalent to published figures for the energy expenditure of men engaged in moderate work.

2. The cadets spent $9 \frac{1}{4} \mathrm{~h}$ a day sitting, some of it at lectures, and $8 \frac{1}{2} \mathrm{~h}$ in bed. Dressing and cleaning uniform occupied more of their time and energy than sport or military training.

3. The supplies issued to the establishment provided $37 \mathrm{I}_{4} \mathrm{Cal} / \mathrm{cadet} / \mathrm{day}$. Of these the cadets took only $68 \%$. Unused bread accounted for a large part of the discrepancy, for the cadets ate only $6.4 \mathrm{oz}$. ( $182 \mathrm{~g}$ ) out of the ${ }^{5} 5 \mathrm{oz}$. $(426 \mathrm{~g})$ of their ration. The plate waste came to $7 \cdot 7 \%$ of the calories in the food served.

4. The cadets then bought at the canteen and in restaurants outside food that provided them with approximately the same number of calories as the portion of their ration not taken up. By refusing their allowance of bread and buying cakes instead, they obtained more fat but less protein than their ration supplied. 
We gratefully acknowledge the co-operation we received from the officers and cadets and the kitchen staff at the institution where this investigation was made. We are also indebted to Mrs L. A. Strangeways, Mr L. A. R. Luff and Mr T. Emerson for all the help they gave us while the investigation was in progress.

\title{
REFERENCES
}

Arneil, G. C. \& Badham, D. R. (1948-9). Brit. F. Nutr. 2, 310.

Edwards, H. T., Thorndike, A. Jr. \& Dill, D. B. (1935). New Engl. F. Med. 2r3, 532.

McCance, R. A. \& Widdowson, E. M. (1946). Spec. Rep. Ser. med. Res. Coun., Lond., no. 235, and ed.

National Research Council (1948). Repr. nat. Res. Coun., Wash., no. I29.

Orr, J. B. \& Leitch, I. (1937-8). Nutr. Abstr. Rev. 7, 509.

Passmore, R., Thomson, J. G. \& Warnock, G. M. (1952). Brit. F. Nutr. 6, 253.

Schenk, P. (1936). Mïnch. med. Wschr. 83, 1535 .

\section{Malnutrition in African Adults}

\author{
1. Serum Proteins, Cholinesterase, and Protein-bound Lipid \\ By MARGARET W. STANIER AND E. G. HOLMES \\ Department of Physiology and R/144 Research Unit, \\ Makerere College, Kampala, Uganda
}

(Received I6 November 1953)

The type of malnutrition most commonly seen in East Africa appears to be due to a deficiency of dietary protein. It is not 'undernutrition', i.e. deficiency of intake of calories and all dietary constituents. Nor do the symptoms suggest a deficiency of any of the known accessory food factors. That the malnutrition is due to inadequate protein intake is suggested both by a consideration of the staple foods and dietary habits of the population and also by the symptoms of adult patients admitted to hospital with a diagnosis of malnutrition.

The serum proteins are obviously of interest in such a condition because they, apart from the proteins of the liver and intestine, have the quickest rate of turnover of any body protein. The changes in serum proteins in inanition are already well known, both from the observations made during famines and food shortages (c.f. Members of the Department of Experimental Medicine, Cambridge, and Associated Workers, 195 I) and from experiments made on human volunteers (Taylor, Mickelsen \& Keys, 1949). However, the changes occurring in a protein deficiency without a calorie deficiency have rarely been studied, because such a state does not often occur in Europe or North America, where mixed diets are eaten. The subjects studied by Youmans, Bell, Donley \& Frank (1932, I933) may perhaps have suffered from such a condition, but it is mainly in underdeveloped parts of the world, where the diets consist of one or two foodstuffs only, that protein deficiency commonly occurs.

We were particularly interested in this question because we had already found that in apparently normal Africans, not suffering from any condition liable to cause anaemia or serum-protein changes, there is a relationship between red-cell count and serum 